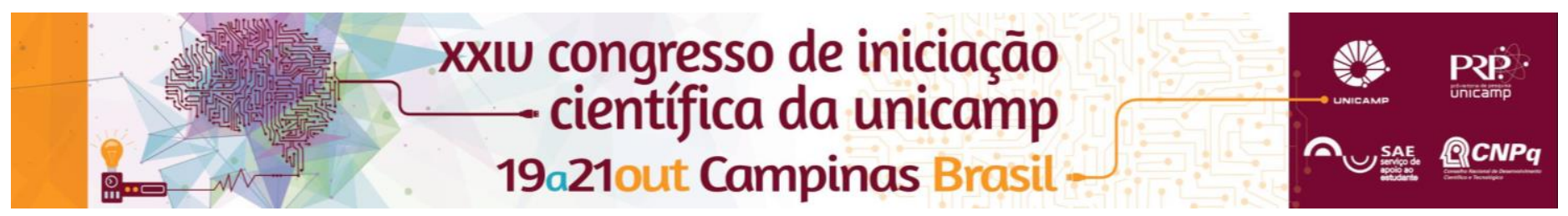

\title{
Structure and Spontaneity in Corporeal Mimesis and Word Mimesis as Premises to think about Stage Presence
}

\section{Andressa Moretti Silva (IC)}

\begin{abstract}
This research is concerning concepts of structure and spontaneity through methodologies of corporeal mimesis and word mimesis that have been developed by LUME (Interdisciplinary Center of Theatrical Research - UNICAMP) and by my academic advisor, Raquel Scotti Hirson. The research includes a practical stage and a theoretical reflection about what we expect to encounter in the work place, such as: physical actions, categorization of materials, corporeal mimesis, word mimesis and stage presence.
\end{abstract}

\section{Key words:}

Stage Presence, Corporeal Mimesis, Word Mimesis.

\section{Introduction}

The research material is collected by observation of transvestites and transsexuals, at streets and nightclubs in the city of Campinas, as well of inhabitants of Jardim Itatinga's neighborhood, also located in Campinas. With this material as a starting point and using the procedures of corporeal mimesis and word mimesis, we try to experiment ways of structuring in the actor's body and voice several physical and vocal actions observed in these environments, working toward the formation and sustainability of a stage presence. We use this experience to reflect upon the binomial relation of structure and spontaneity, specially concerning the question of organization and categorization of the material collected during the observation. The practical experiments are the basis for discussing whether presence and spontaneity can be related and in which way this happens in an acting job.

\section{Results and Discussion}

According to LUME, the corporeal mimesis is a methodology of creating physical and vocal actions seeking poeticization and dramatization of affective meetings between actor-observer and bodies / materials / images. The assumption of the corporeal mimesis is that this meeting may potentiate the transformation and the recreation of the body, which is acting. In the corporeal mimesis, observation, it is in a body sensation-image accessed by images of texts, poems and everyday conversations. In the course of the investigation, I participated in collective trainings with other students supervised by actors/researchers of the LUME Theatre and I realized the corporeal apprehension of matrices from observing transvestites, transsexuals, and the use of texts and filmographies related to the theme. This research uses corporeal mimesis procedures and the word mimesis as premises for thinking of stage presence. Finding a definition for what is stage presence is not a simple task because the concepts are multiples and sometimes contradictories. There are theater directors who believe it is possible to build the stage presence through training. For Eugenio Barba, for example, presence is what acts on the viewer (Féral, 2001, p.97), for the Canadian director Pol Pelletier it is more body awareness that something is to be achieved with precise methods of physical work. (Féral,
2012, p. 27). On the other hand, Ariane Mnouchkine, for example, does not use the concept of stage presence in her work, but she believes that the actor should be in the present, act and react according to the play. Anchored in my practical experience, I believe it is possible to reach a stage presence through actor's training, but to widen the issue to reflect on how to pass the presence status for the creation of state, that is, how to build poetically with this body enhanced by training and how to resume it in improvisations and scenic creations. I think that relate the training practices of corporeal mimesis and word mimesis is a good way to improve this research because mimesis leads to the creation of corporeal-vocal matrices and consequently poeticizing them.

\section{Conclusions}

The course of research helped me to experience the binomial structure and spontaneity and to investigate, through the procedures of corporeal mimesis and word mimesis and ways to search to raise scenic presence effects. The search for a stage presence is continuous and takes place in the present work, in relations with my peers or in the workroom space and the elements that accompanied me in the research: photos and videos. The understanding that it was possible to achieve this result through training was through a good mix of practical trials and theoretical reflections of concepts such as impulses, sats, precision, and qualities of energy, personal associations and images, balance of the limit of imbalance, structure, and spontaneity and stage presence. The research does not provide a poetic creation and presentation, but I hope to make projections on how the work can overflow scenic creations.

\section{Acknowledgement}

To FAPESP funding program (Fundação de Amparo à Pesquisa do Estado de São Paulo).

To Raquel Scotti Hirson, supervisor of this research at UNICAMP (State University of Campinas).

To Josette Féral, supervisor of this research at University of Paris 3: Sorbonne Nouvelle.

\section{References}

FÉRAL, Josette. Mise enscène et Jeu de l'acteur Entretiens. Tome 2: Le corps en scène Éditions Jeu/Éditions Lansman, 2001.

Josette. Pratiques Performatives - Body Remix. Presses de

l'université du Québec, 2012. 